IRA-International Journal of Management \& Social Sciences

ISSN 2455-2267; Vol.04, Issue 01 (2016)

Institute of Research Advances

http://research-advances.org/index.php/RAJMSS

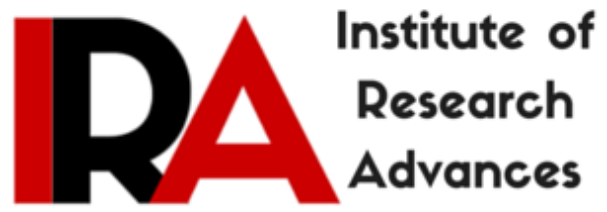

\title{
Predicament of Dalits in the Select Poems Of Meena Kandasamy
}

C. Shanmuga Priya, (M.A, M. Phil.,SET.,)

Assistant Professor, Department of English, Srimad Andavan Arts and Science College(Autonomous), Trichy - 620005, Tamil Nadu, India.

DOI: http://dx.doi.org/10.21013/jmss.v4.n1.p24

\section{How to cite this paper:}

Priya, C. (2016). Predicament of Dalits in the Select Poems of Meena Kandasamy. IRAInternational Journal of Management \& Social Sciences (ISSN 2455-2267), 4(1). doi:http://dx.doi.org/10.21013/jmss.v4.n1.p24

(C) Institute of Research Advances

\section{(c)) EY-NO}

This works is licensed under a Creative Commons Attribution-Non Commercial 4.0 International License subject to proper citation to the publication source of the work.

Disclaimer: The scholarly papers as reviewed and published by the Institute of Research Advances (IRA) are the views and opinions of their respective authors and are not the views or opinions of the IRA. The IRA disclaims of any harm or loss caused due to the published content to any party. 


\section{ABSTRACT}

Dalit Literature is the writings about dalits whose primary motive is the liberation of dalits. Dalit writers have provided useful insights on the question of Dalit identity through their poems, short stories, novels and autobiographies. They have given a dignified status to the Dalits liberating them from the sub-human lot imposed on them by the Hindu social order. They use the language of the out-castes and underprivileged in Indian society, with their sharp expression. This paper explores the sensible portrayal of the predicament to the outcastes in Indian society in her select poems.

Key Words: Dalit Literature, Dalits, Out-castes, Under-privileged, Indian society.

\section{Introduction}

"Dalit Literature is not a literary movement in ordinary sense of the term. It is, like Black literature, a product of an identity as well as constitutive of that identity" points out Shashi Bhushan Uphadhayay. In 1950s and 1960s, Dalit writing saw the emergence of literature with the publication of Sathe's "Fakira" and "Savala Mang" and Shankarrao Karat's "Manuskichi Huk" (The Cry of Humanity) and "Bara Balutedar"(The Twelve Balutedar). All these writers revolted against the old notions based on Manusmriti or the part of old Brahmin society. It was at its zenith during the time of Ambedkar but it declined and reached its anticlimax in 1970s. More dalit persons began to improve the situation of Dalit through their writings with great zeal after their higher studies abroad and their return to India. Their aim was not to bring the lowness of the dalit society but to highlight the real picture of the plight of the dalits. They brought a close and real imagery as obviously true in the case with Mulk Raj Anand's "Untouchable" and "Coolie". Poems, short stories, novels and autobiographies written by Dalit writers provided useful insights on the question of Dalit identity. Dalit poetry is an effort to employ symbolic images based on the experience breaking many old poetic conventions of literature. They bring in historic references and myths from a dalit point of view.

\section{Dalit literature}

The primary motive of Dalit literature is the liberation of dalits. Though Dalit writers have had their hands in short stories, novels and drama, the richness lies in poetry with the crying theme of "new past, new future". The first collection of dalit poems by dalits entitled "Akar" was published in 1967. The most notable among dalit poets are Narayan Surve, J.V.Parvar, Nimbalkar, Arun Kamble, Prakash Jadhav etc., among men and Mina Gajbhiye, Hira Bhanshode, Jyoti Lanjewar, Mallika Amar Shiekh, Anuradha Gurav, Meena Kandasamy etc., among women. A dalit poem is unique in the sense that it builds its structural pattern out of Dalit sensibility. It is, thus a poetry of protest, voicing its opposition to all that is orthodox, traditional and conventional. Persecution, Love for India, Subversion of history and myth are the recurrent themes of Dalit poetry. Dalit poetry may be said to centre around man. Eleanor Zelliot expresses about the poems of women Dalit writers as "their voices are strong and varied, echoing other dalit themes but adding new images, new perspectives and new languages".

\section{Meena Kandasamy as a poet}

Meena Kandasamy, based in Chennai, is an emerging poet, fiction writer, translator and activist. Her first volume of poems Touch was published in 2006. Her poetry has won many laurels in poetry competitions. Her translations include the writings and speeches of Thol.Thirumavalavan, leader of Viduthalai Chiruthaigal or Dalit panthers of India, and the poetry and fables of Tamil Eelam poet, Kasi Anandan. She is one of the 21 short fiction writers from South Asia featured in an anthology published by Zubaan, New Delhi. At present, she is working on her doctorate on caste in the Indian language classroom. There is fierce and exuberant wit and wordplay in Meena's works. The Indo-Anglian poet, Kamala Das, is all praise for Meena's verse that "she wore a fabric rare and strange, faintly smudged with 
the Indianness of her thought that saw 'even the monsoons come leisurely stroking like decorated temple elephants"' in her foreword to Meena's Touch. The poetics of 'an angry young woman' as Meena Kandasamy describes herself is filled with relentless militant assaults on the structures, customs and conventions which have persistently been used to justify and then gloss over Dalit subjugation of various kinds. Her poetry collections Touch and Ms. Militancy not only touch upon aesthetic considerations and sensual human bonds of affection or desire but refers to the rigid hierarchies of caste that relegate them to a sub-human level as their mere touch is considered to be polluting to the upper caste people. The present paper analyzes the subjugation of women in the select poems of Ms. Militancy under which Back-Street Girls, Dead woman walking, Fire-walkers, Ms. Militancy, Princess-in-Exile, Moon-gazers and One Eyed are discussed and analyzed.

\section{Analysis of the poems in Ms. Militancy}

Back-Street Girls is a poem that draws women to the independence enjoyed by men breaking all constraints. Meena's women need not chain themselves by the rules anymore. They can act according to their whims and fancies. They need not confine themselves within the iron bars of culture and tradition. They have the liberty to play roles such as 'sluts, gluttons, bitches, witches and shrews'. No manu can control them. They are independent enough to choose men as their husbands and "strip random men". The poem liberates women from their subjugation and highlights them as we (women) are not the ones you can sentence for life (14).

Dead woman walking throws light on the hardships and emotional stress of the downtrodden, abandoned women. She has brought in the mythological character, Karaikkal Ammayar who stands for the dalit women who are sexually exploited by men. Karaikal Ammayar was deserted by her merchanthusband to marry "a fresh and formless wife" inspite of her beauty and "the magic of my (her) multiplying love". Her love for Lord Shiva posed her to be a mystic in the eyes of her husband. Meena expresses the pain of deserted women through the mouth of Karaikkal Ammayar as i wept in vain, $i$ wailed, $i$ walked on my head, $i$ went to god(17). The society viewed her as a mad woman living with faltered step, felted flying hair, hollowed cheeks and bulging eyes.

i am a dead woman walking asylum corridors,

with faltering step,with felted flying hair,

with hollowed cheeks that offset bulging eyes,

with seizures of speech and song, with a single story

between my sobbing pendulous breasts

The poem sarcastically underlines how such women die while they are physically alive.

Fire-walkers epitomizes the plight of poor women exploited by upper class people. The poet lashes at the conventional belief of the people in making offerings to the Goddess Maari. She portrays Maari as the exploiter who extracts pleasure from the pains of her devotees, who are depicted as the dream chasers, the firewalkers(22). They burn and whip their bodies to satisfy Her. Maari represents the inhuman oppressors of the dalits who is appeased by the violent sacrifices of innocent people.

Ms. Militancy, the title poem of the volume, is based on the heroine of the Tamil Classic Silapathikaram, Kannaki. Kannaki has been dedicated and loyal to her betrayal-imaged husband Kovalan even after his return from his dancer-mistress Madhavi. Though this displays the patriarchal dominance, the rage she shows at the death of her husband asserts her as a bold revolutionist. Such a 
militant woman is the woman that Meena Kandasamy dreams of. She is the role-model for the subjugated women to come out of their cocoons.

Princess-in-Exile is about Sita who "walked out" of her place from her husband Rama, when her chastity was questioned. She indirectly avenges her husband for his suspicion on her. Likewise, Meena wants women not to follow the rules laid by the patriarchal society.

$$
\begin{aligned}
& \text { scorned, she sought refuge in spirituality, } \\
& \text { and was carried away by a new-age guru } \\
& \text { with saffron clothes and caramel words } \\
& \text { years later, her husband won her back } \\
& \text { but by then, she was adept at walkouts, } \\
& \text { she had perfected the vanishing act. }
\end{aligned}
$$

Moon-gazers is a powerful rendition of the superiority of non-dalits over the dalits. The poet brings home the speechless predicament of the dalits through the analogy of a classroom situation. The teacher talks about a bird watching throughout the night. When a girl questions what the bird does on new moon days, she is laughed at. She could not get an answer but just staring at the limitless eyes of the teacher. Such is the fate of all the dalits remaining mute and spell-bound to the atrocities inflicted on them.

One Eyed, the short poem highlights various atrocities committed against the dalit women. Meena emphasizes the humanitarian attitude of inanimate things which human beings lack. The pot, the glass and the water quench the thirst of a person while the teacher, the doctor, the school and the press are indifferent to the needs of the people. The dalit woman Dhanam was "torn in half"(41) when she tries to get a pot of water at the cost of her left eye.

the teacher sees a girl breaking the rule

the doctor sees a medical emergency

the school sees a potential embarrassment

the press sees a headline and a photofeature

dhanam sees a world torn in half

her left eye, lid open but light slapped away,

the price for a taste of that touchable water.

\section{Conclusion}

Thus, Meena has themes and diction that are taboos in the cultural context of India. As Ranjit Heskote, in his review of Ms. Militancy has rightly puts it "there is considerable current of surprise and elusiveness that does battle with the strain of predictability in Kandasamy's poetry; even when she rehearses a well established choreography of feminist self-assertion, she does so with a sharp eye for detail, a grasp of worldly insight and an appetite for phrasal shape-shifting". Needless to say, Meena's poetry stands a testimony to her stance in Dalit literature and in Indian English literature at large. 


\section{REFERENCES}

1.Dangle, Arjun, ed.: Poisoned Bread, Bombay, Orient Longman publishers, 1992.

2.Kandasamy, Meena. Ms. Mililtancy. New Delhi: Navayanya Publishing, 2010.

3. Ranveer, Kashinath, ed., The Downtrodden India, a journal, pp.80.

\section{WEBSITES}

1.Kandasamy, Meena. "let -there- be-light".

2. www.jpcs.in 